\title{
STUDY OF REGIONAL DRAINAGE CHANNEL CAPACITY AT ALOON-ALOON PONOROGO REGENCY
}

\author{
I Wayan Mundra ${ }^{1}$, Endro Yuwono ${ }^{2}$, Nenny Roostriawaty ${ }^{3}$, Dodik Prasetyo ${ }^{4}$ \\ ${ }^{1,2,3}$ Civil Engineering Department, Institut Teknologi Nasional Malang, Malang, 65145, \\ Indonesia \\ ${ }^{4}$ Graduate School of Civil Engineering Department, Institut Teknologi Nasional Malang, \\ Malang, 6515, Indonesia \\ e-mail:wmundra@yahoo.com
}

\begin{abstract}
The rate of population growth in urban areas is increasing year by year, so that changes in land use will accompany it and have an impact on reducing catchment areas. One of the problems that arise is flooding or inundation. In addition to providing inadequate catchment areas, the existing urban drainage system often does not function optimally with various technical and non-technical problems. One of the urban areas experiencing a similar situation is Ponorogo City, Ponorogo Regency. In some areas of the city, there are still frequent flooding/inundation. For example, in the Ponorogo Regency Government Center, especially around Aloon City. This problem is the background of this study. The results of the study show that the planned flood discharge with a return period of 10 years, which was analyzed based on the modified Rational method, was $0.899 \mathrm{~m}^{3} / \mathrm{s}$. Based on data from observations of the existing drainage system, the channel capacity analyzed by the Maning method is only 0.471 $\mathrm{m} 3 / \mathrm{sec}$. Thus the channel capacity needs to be increased. By widening the rectangular base of the channel from $1 \mathrm{~m}$ wide to $1.50 \mathrm{~m}$, the channel capacity becomes $0.925 \mathrm{~m}^{3} / \mathrm{s}$, so that it can serve according to the planned flood discharge. In addition to increasing the channel capacity, based on observations in the field, it is also necessary to immediately carry out maintenance and repair work on the existing drainage system, so that the function of the channel can be optimal. It is necessary to study the plan to construct infiltration wells in the study area.
\end{abstract}

Keywords: Drainage; Inundation; Flood Discharge.

\section{Introduction}

The rate of population growth in urban areas is increasing year by year, so that changes in land use will accompany it and have an impact on reducing catchment areas. One of the problems that arise is flooding / inundation. In several cities in Indonesia, the problem of flooding / inundation is almost every year, and even tends to increase, both in frequency, breadth, depth and duration. Flood is a puddle of water on the ground to exceed a certain height limit which results in losses [1]. 

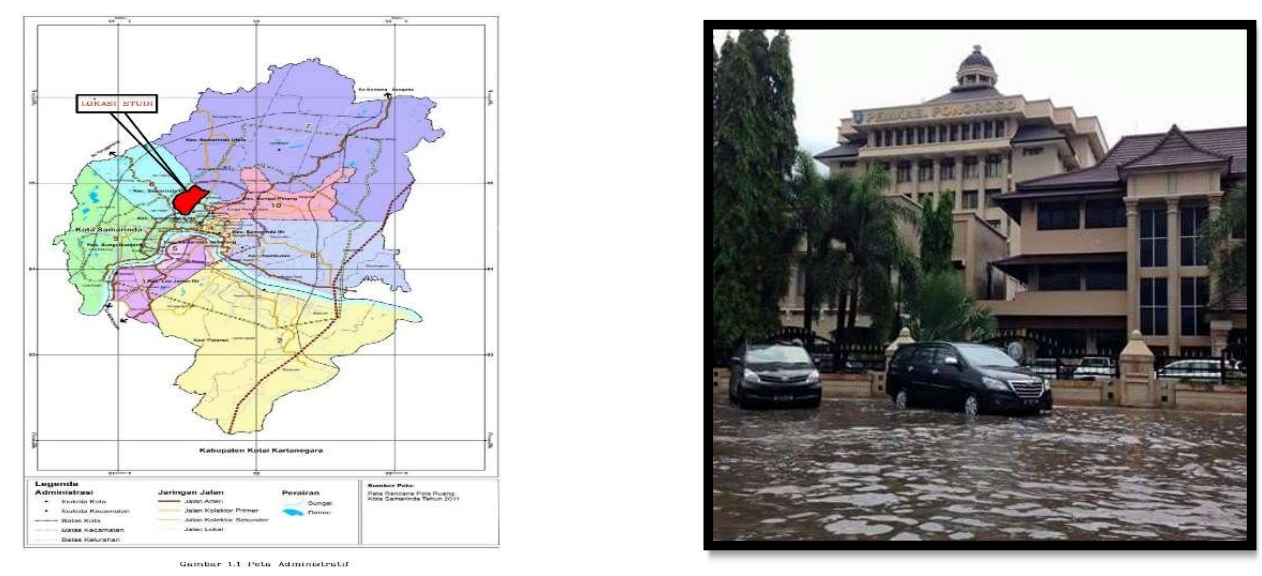

Figure 1. Study Location

In addition to providing inadequate catchment areas, the existing urban drainage system often does not function optimally with various technical and non-technical problems. The urban drainage system must be based on the problem of urban flooding, the main cause of which [2] is the rate of population growth caused by rapid urbanization, imbalance between urban facilities and infrastructure, land changes occur, so that land use in urban areas becomes irregular and increases surface runoff. Urban inundation/flooding can also be caused by a poor drainage system or the dimensions of each channel segment are not in accordance with the discharge served [3].

Ponorogo Regency is one of the regencies in East Java Province whose administrative area is bordered by the following areas; Madiun Regency in the north, Wonogiri Regency in the west, Pacitan Regency in the south and Trenggalek Regency in the east. North Aloon-Aloon Street is one of the important traffic accesses in Ponorogo Regency. This road is right in front of the government center of Ponorogo Regency. This road section has a channel along the road on both sides. However, during the rainy season with high intensity, there are always floods/puddles of water with a height ranging from $20-50 \mathrm{~cm}$. This inundation occurs because the existing infiltration land is no longer able to absorb the rain that falls, so that the flow of rainwater that goes to the drainage channel increases. As a result, the existing drainage system is unable to accommodate the water discharge.

Based on the problems above, the authors conducted a study on the evaluation of the drainage system on North Aloon-Aloon Street, Ponorogo City and its surroundings, so that technical problems can be identified, such as the amount of flood discharge, layout and capacity of the drainage system, and how efforts need to be made to increase system capacity. The results of this study are expected to be used as material for technical considerations by related agencies under the Ponorogo Regency Government to overcome flood problems in the urban area of Ponorogo City, especially in the area around the Central Government/North Aloon-aloon and its surroundings.

\section{Material and Methods}

The research was conducted on 2021 during rainy season between October to December. Within the scope of civil engineering, drainage is limited as a series of water structures that function to reduce or remove excess water from an area or land, so that land can be used optimally according to interests. drainage plays an important role in regulating water supply for flood prevention [4] [11]. Based on the formation of the drainage system, it is divided into natural drainage (natural drainage) and artificial drainage, while based on the drainage system which is divided into drainage with a network system and drainage with an infiltration system [5].

A network drainage system can be defined as a series of water structures that function to reduce and/or remove excess water from an area or land. Viewed from the upstream side, the drainage system consists of an interceptor drain, a collector drain, a main drain and a conveyor drain. Along 
the system, other buildings are often found, such as culverts, siphons, aquaducts, spillways, sluice gates, waterfall structures, reservoir ponds and pumping stations. In a complete drainage system, before entering the receiving water body, it is treated first at the wastewater treatment plant (IPAL), especially for mixed systems. Only water that has a certain quality standard is entered into the receiving water body, usually a river, so that it does not damage the environment [6].

\subsection{Plan flood discharge}

The design flood discharge or design flood discharge is the maximum discharge in a river or channel with a predetermined return period that can be flowed. The design flood discharge is generally planned to drain flood water as soon as possible so that there will be no puddles that interfere with community activities [1]. Subarkah, 1980 mentioned that there are several methods that can be used in analyzing the planned flood discharge, one of which is the modified Rational method which is the development of the Rational method for rainfall intensity that is longer than the time of flow concentration.

$$
Q=0,278 . C_{s} . \text { C.I.A }
$$

With:

$$
\begin{aligned}
\mathrm{Q} & =\text { maximum flood discharge }\left(\mathrm{m}^{3} / \mathrm{s}\right) \\
\mathrm{Cs} & =\text { holding coefficient }=2 \mathrm{tc} /(2 \mathrm{tc}+2 \mathrm{td}) \\
\mathrm{Tc} & =\text { concentration time (minutes) } \\
\mathrm{Td} & =\text { length of flow in the channel (minutes) } \\
\mathrm{C} & =\text { runoff coefficient } \\
\mathrm{I} & =\text { average rainfall intensity during the time of arrival from the flood }(\mathrm{mm} / \mathrm{hour}) \\
\mathrm{A} & =\text { area of drainage }\left(\mathrm{km}^{2}\right)
\end{aligned}
$$

The runoff coefficient $(\mathrm{C})$ can also be used to determine the physical condition of the drainage area (Subdas). The value of $\mathrm{C}$ ranges from $0-1$. The value of $\mathrm{C}=0$ indicates that all rainwater is intercepted and infiltrated into the soil, on the contrary for $\mathrm{C}=1$ indicates that rainwater flows as surface runoff [8].

Rain intensity analysis begins with an analysis of the planned rainfall distribution. Analysis of the planned rainfall distribution is intended to determine the maximum daily rainfall in a certain return period. The method used for calculating the rainfall in this plan is the Gumbel method, the Normal method, the Log Normal method and the Log Person III method [9]. Of the four methods, a frequency test was conducted which aims to determine the truth between the observations and the expected distribution model. or who obtain theoretically and know whether the hypothesis is accepted or rejected [4], using the Chi-squared test and the smirnov-kolmogorov test method.

\subsection{Concentration Time}

Concentration time is the time required for rainwater that falls to flow from the far point to the watershed outlet (control point) after the soil becomes saturated and small depressions are filled. The concentration time can be calculated by dividing it into two components, namely:

1. The time required for water to flow over the land surface to the nearest channel and

2. Travel time from first line entry to output point td, so that

$$
\begin{aligned}
& t_{c}=t_{1}+t_{2} \\
& t_{1}=\left[\frac{2}{3} \times 3,28 \times \text { lo } \times \frac{n d}{\sqrt{l s}}\right]^{0,167} \\
& t_{2}=\frac{L}{60 \mathrm{~V}}
\end{aligned}
$$

With:

$\mathrm{t} 1$ = time to reach the start of the channel from the farthest point (minutes)

t2 = flow time in the channel along L from the end of the channel (minutes)

nd $=$ drag coefficient

ls = Channel slope length 


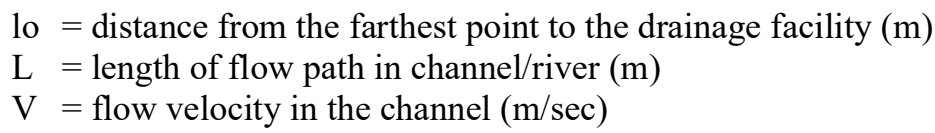

\subsection{Runoff coefficient}

The runoff coefficient $(\mathrm{C})$ is a number that displays the ratio between the amount of runoff and the amount of rainfall. The value of $\mathrm{C}$ ranges from $0-1$. The value of $\mathrm{C}=0$ indicates that all rainwater is intercepted and infiltrated into the soil, whereas the value of $\mathrm{C}=1$ indicates that rainwater flows as surface runoff. In a good watershed the price of $\mathrm{C}$ is closer to 0 and the more damaged a watershed is, the price of $\mathrm{C}$ is getting closer to 1 .

The runoff factor ( $\mathrm{fk}$ ) is a factor or number multiplied by the usual runoff coefficient with the aim that the channel performance does not exceed its capacity due to the drainage area being too wide. The runoff factor value (fk) is adjusted to the soil surface conditions.

$$
C=\frac{C_{1} \cdot A_{1}+C_{2} \cdot A_{2}+C_{3} \cdot A_{3 . f k_{3}}}{A_{1}+A_{2}+A_{3}}
$$

With:

$\mathrm{A}=$ area of drainage area

$\mathrm{C}=$ surface runoff coefficient according to the type of surface condition

$\mathrm{fk}=$ runoff factor according to land use

\subsection{Rain intensity}

To determine the planned flood discharge, it is necessary to obtain a price for the intensity of rainfall. Rain intensity is the height or depth of rainwater per unit time.

The method used to calculate the intensity of rain is the method of Dr. Mononobe. This method is used if the available rainfall data is daily rainfall.

$$
I=\frac{R}{24}\left(\frac{24}{t c}\right)^{\frac{2}{3}}
$$

With:

$\mathrm{I}=$ rainfall intensity $(\mathrm{mm} /$ hour $)$

$\mathrm{R}=$ maximum rainfall in 24 hours $(\mathrm{mm})$

$\mathrm{Tc}=$ duration of rain/concentration time (hours)

\subsection{Channel capacity}

Determination in determining the amount of water discharge that must be flowed through drainage channels in certain areas is very important in determining channel dimensions. Channel dimensions that are too large will have an uneconomical value, but if they are too small they will have a high level of failure. Calculating the amount of the planned discharge is generally done using the rational method. This is because the area of the watershed is not too wide, the water loss is small and the concentration time is relatively short [7].

Channel capacity aims to determine the ability to channel/pass water (discharge). Channel dimensions are determined based on the maximum Q, flow velocity, channel slope, and the type of channel material to be used [10].

$$
Q=A x V
$$

With:

$\mathrm{Q}=$ Water discharge ( $\mathrm{m}^{3} /$ second $)$

$\mathrm{A}=$ cross-sectional area $\left(\mathrm{m}^{2}\right)$

$\mathrm{V}=$ flow rate $(\mathrm{m} / \mathrm{s})$ 


$$
\begin{aligned}
& V=\frac{1}{n} x R^{\frac{2}{3}} x S^{\frac{1}{2}} \\
& S=\frac{\Delta h}{L} \\
& R=\frac{A}{P}
\end{aligned}
$$

With:

$\mathrm{Q}=$ Water discharge ( $\mathrm{m} 3 /$ second $)$

$\mathrm{A}=$ cross-sectional area $(\mathrm{m} 2)$

$\mathrm{V}=$ flow rate $(\mathrm{m} / \mathrm{s})$

1. Square channel

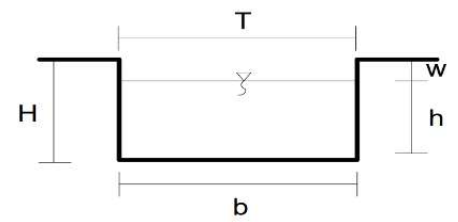

Figure 2. Penamapang saluran segi empat

$$
A=b x h \quad P=b+2 h
$$

With:

$\mathrm{A}=$ channel cross-sectional area $\left(\mathrm{m}^{2}\right)$

$\mathrm{P}=$ wet circumference $(\mathrm{m})$

$\mathrm{b}=$ channel bottom width $(\mathrm{m})$

$\mathrm{h}=$ water level $(\mathrm{m})$

$\mathrm{w}=$ guard height $(\mathrm{m})$

2. Trapezoidal channel

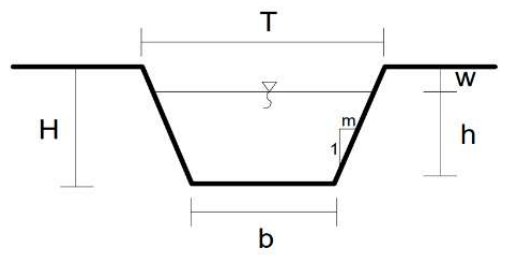

Figure 3. Trapezoidal channel cross-section

$$
A=(b+m h) h \quad P=b+2 h \sqrt{m^{2}+1}
$$

With:

$A=$ cross-sectional area $\left(\mathrm{m}^{2}\right)$

$\mathrm{P}=$ wet circumference $(\mathrm{m})$

$\mathrm{b}=$ channel bottom width ( $\mathrm{m}$ )

$\mathrm{m}=$ slope $(\mathrm{m})$

$\mathrm{h}=$ water level $(\mathrm{m})$

$\mathrm{w}=$ guard height $(\mathrm{m})$ 


\section{Result and Discussion}

\subsection{Flood/inundation area}

Based on data from the existing canal system obtained from the Water Resources of Public Works Department of Ponorogo Regency and supported by field observations, the area that experiences regular flooding/inundation during high rainfall seasons is North Aloon - Aloon Street, Mangkujayan Village. Ponorogo Regency.

The channel with water bodies (a river that accommodates and continues flood discharge downstream which ultimately leads to the sea, there is no need to change the layout. Observing the condition of the channel in the field, it is possible to increase the channel capacity. For this reason, a discharge analysis will be carried out flood first and then the channel capacity analysis will be carried out for comparison, so that planning for the required channel capacity can be known and carried out.

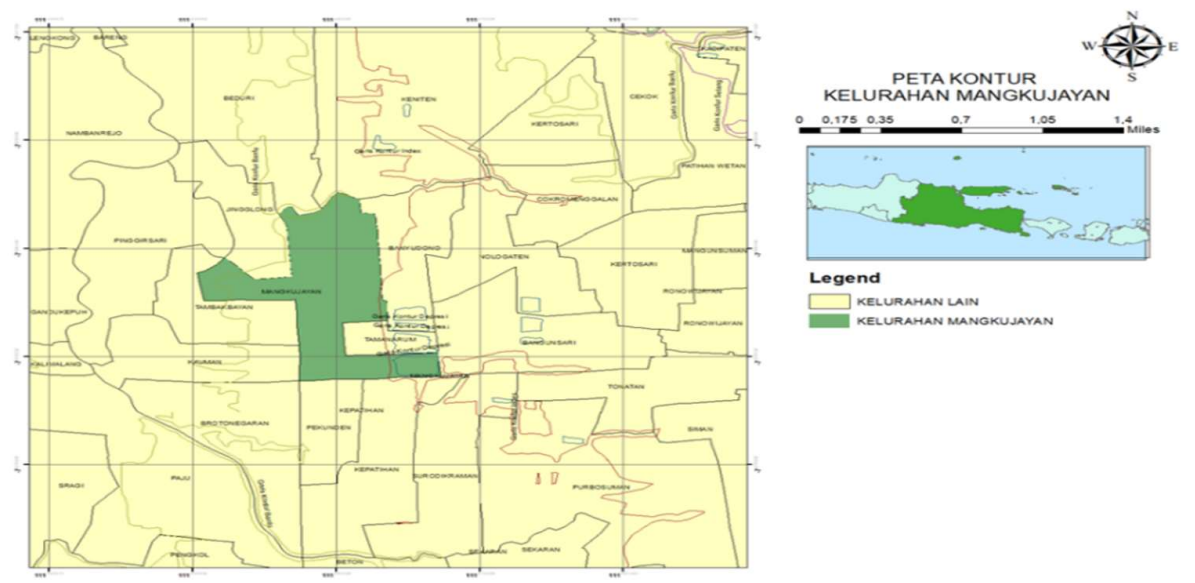

Figure 4. Flooded Areas/which often Experience Inundation
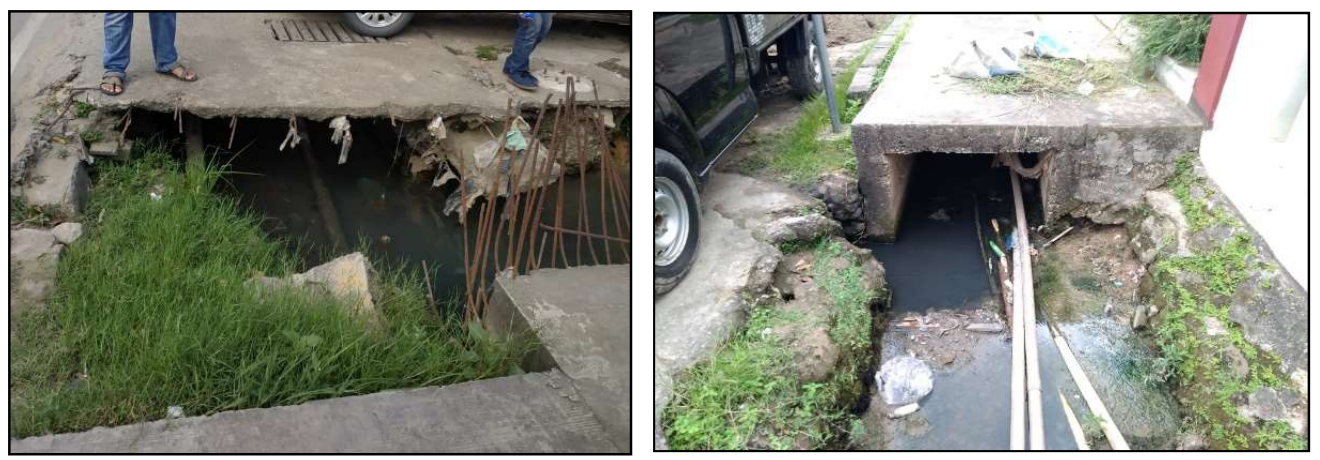

Figure 5. Existing Channel Condition

\subsection{Plan Flood Discharge}

Based on the analysis of maximum daily rainfall based on daily rainfall data for the last 10 years (2010 to 2019), from the 3 closest rain stations, namely Ponorogo Station, Simoroto Station, and Babadan Station, the maximum rainfall value was $114.67 \mathrm{~mm}$. Based on the magnitude of the rain, then an analysis of the intensity of the rain with a period of 2 years, 5 years and 10 years. The results of the design rain height analysis can be checked in the following table. 
Table 1. Summary of The Calculation of Design Rain Height

\begin{tabular}{ccccc}
\hline $\begin{array}{c}\text { Return } \\
\text { Period }\end{array}$ & $\begin{array}{c}\text { Normal } \\
(\mathrm{mm})\end{array}$ & $\begin{array}{c}\text { Log } \\
\text { Normal } \\
(\mathrm{mm})\end{array}$ & $\begin{array}{c}\text { Log Person } \\
\text { III }(\mathrm{mm})\end{array}$ & $\begin{array}{c}\text { Gumbel } \\
(\mathrm{mm})\end{array}$ \\
\hline 2 & 88.37 & 87.61 & 86.29 & 86.67 \\
5 & 98.90 & 98.25 & 97.12 & 101.64 \\
10 & 104.42 & 104.32 & 105.04 & 111.54 \\
\hline
\end{tabular}

Source: Data Analysis, 2021

After calculating the planned rain height using the Normal, Log Normal, Person III, and Gumbel methods. then the dispersion test and chi square test were carried out to find out the frequency distribution that met the statistical parameter requirements in the calculation of planned rainfall. Based on the results of the analysis, it is known that of the four calculation methods used, only the Gumbel Method (111.54 $\mathrm{mm}$ ) meets the requirements.

Furthermore, the analysis of the planned flood discharge on the channel section in North AloonAloon Street which causes massive flooding/inundation in the surrounding area is as follows:

1. The average runoff coefficient $(\mathrm{C})$ analyzed based on the land use conditions of the rainwater catchment area, which is mostly a pavement layer with very low rainwater infiltration capability, which is 0.95 . While the catchment area of rainwater (A) for the channel section under review is $2,095 \mathrm{~km} 2$. Concentration time $(\mathrm{Tc})$, which is the time required when rainwater falls at the beginning of the upstream channel to the downstream point of the channel is 11.35 minutes.

2. The amount of rainfall intensity will use the value analyzed by the Gumbel method because statistically the method is acceptable (qualifies). The height of the rain used is the height of the rain with a return period of 10 years, which is $111.54 \mathrm{~mm}$. Thus, the value of the amount of rain intensity (I) using the Mononobe method is $117.28 \mathrm{~mm} / \mathrm{hour}$

3. The planned flood discharge with a return period of 10 years, analyzed based on the modified Rational method is as follows:

$$
\begin{aligned}
Q_{10} & =0.278 C I A \\
& =0.278 \times 0,95 \times 117,28 \times 2.095) \\
& =0.899 \mathrm{~m}^{3} / \mathrm{det}
\end{aligned}
$$

\subsection{Existing Channel Capacity}

Analysis of the capacity of the existing channel is carried out to determine the ability of the drainage channel to drain flood discharge. Based on the channel dimension measurement data in the field, the following data were obtained:
1. Channel shape
$=$ rectangle
2. Channel length (L)
$=170 \mathrm{~m}$
3. Depth (h)
$=1 \mathrm{~m}$
4. Channel bottom width (b)
$=1 \mathrm{~m}$
5. Manning roughness coefficient $(\mathrm{n})=0.03$
6. Channel base slope (S)
$=0.0006$

The flow velocity in the channel based on the velocity equation according to the Manning method is $0.471 \mathrm{~m} / \mathrm{s}$. With a cross-sectional shape like the data above, the channel capacity is 0.471 $\mathrm{m} 3 / \mathrm{s}$.

If the canal capacity is compared with the amount of flood discharge that occurred (calculated for flood discharge with a return period of 10 years), which is $0.899 \mathrm{~m} 3 / \mathrm{s}$, then the channel capacity can be declared unable to drain flood discharge. Thus, it is necessary to increase the channel capacity. 


\subsection{Increasing the capacity of the existing channel}

Taking into account the general shape of the urban drainage channel, which is rectangular, the shape of the channel in the study area is also maintained in a rectangular shape. This is also seen from the types of channels made of pre-cast concrete, which are generally also rectangular in shape. By trial and error that has been done in the calculation process, the channel dimensions are determined as follows:
1. Channel shape
$=$ rectangle
2. Channel length (L)
$=170 \mathrm{~m}$
3. Depth (h)
$=1 \mathrm{~m}$
4. Width of duct base (b)
$=1.5 \mathrm{~m}$
5. Manning roughness coefficient $(\mathrm{n})=0.03$
6. Channel base slope (S)
$=0.0006$

Obtained the flow velocity in the channel based on the velocity equation according to the Manning method of $0.617 \mathrm{~m} / \mathrm{s}$. With the cross-sectional shape like the data above, the channel capacity is $0.925 \mathrm{~m}^{3} / \mathrm{s}$.

When compared between the planned flood discharge and the planned channel capacity, it is $0.899 \mathrm{~m}^{3} / \mathrm{s}: 0.925 \mathrm{~m}^{3} / \mathrm{s}$. Thus, the specified channel dimensions can be said to be qualified. In addition to increasing channel capacity, based on observations in the field, it can be shown 3 important things to be followed up immediately, namely:

1. There is deposition of sediment and garbage in several canal sections which reduces the capacity of the existing canal and hampers the flow of flood discharge, thereby accelerating the occurrence of flooding/waterlogging in the study area. It needs to be cleaned immediately, so that the channel function returns to normal

2. Several sections of the canal and its appendages are also damaged and need to be repaired immediately, so that the function of the drainage canal can be optimized.

3. Lack of open green spaces which become natural rainwater infiltration spaces due to the density of various urban infrastructures. It is necessary to study the drainage system of infiltration wells as an alternative to an environmentally sound drainage system.

\section{Conclusion and Suggestion}

Based on the results of the Study of Drainage Channel Capacity in the Aloon-aloon Region of Ponorogo Regency, several conclusions can be drawn, namely:

1. Taking into account the layout of the channel with the body of water (a river that accommodates and transmits flood discharge downstream which ultimately leads to the sea, there is no need to change the layout.

2. The amount of rainfall intensity with a return period of 10 years, based on daily rainfall data for the last 10 years (2010 to 2019), from the 3 closest rain stations, namely Ponorogo Station, Simoroto Station, and Babadan Station, the maximum rainfall value was $114.67 \mathrm{~mm}$. The magnitude of the design flood discharge with a return period of 10 years is $0.899 \mathrm{~m} 3 / \mathrm{s}$. The result of the analysis of the existing channel capacity is $0.471 \mathrm{~m} 3 / \mathrm{s}$. From the results of the analysis, it can be said that the channel capacity is not able to drain the planned flood discharge, so it is necessary to plan to increase the channel capacity.

3. Increasing the channel capacity is done by increasing the width of the existing channel from $1 \mathrm{~m}$ wide to $1.5 \mathrm{~m}$ and other dimensions are fixed, then the channel capacity becomes 0.925 $\mathrm{m} 3 / \mathrm{sec}$. (analyzed by the Manning method). Based on the results of the analysis, the channel capacity will be able to drain the planned flood discharge with a return period of 10 years.

In addition to increasing channel capacity, based on observations in the field, it is suggested that there are 3 important things to be followed up immediately, namely:

1. There is deposition of sediment and garbage in several canal sections which reduces the capacity of the existing canal and hampers the flow of flood discharge, thereby accelerating the occurrence of flooding/waterlogging in the study area. 
2. Several sections of the canal and its accessories were also damaged, requiring immediate repairs, so that the function of the drainage canal can be optimized again.

3. Lack of open green spaces which become natural rainwater infiltration spaces due to the density of various urban infrastructures. It is necessary to study the plan for the construction of infiltration wells.

\section{References}

[1] Arif Siswanto dkk., 2021, Kajian Evaluasi Kapasitas Tampung Saluran terhadap Debit Banjir Rancangan pada Perencanaan Sistem Jaringan Drainase Kota Kandangan, Bowplank Vol. 1 No. 1, Februari, Universitas Widyagama Malang, Malang.

[2] Rafianda Adela Putra dkk., 2019, Perencanaan Sistem Penyaluran Drainase di Kecamatan Hamparan Rawang, Kota Sungai Penuh, EnviroSan Vol. 2, Nomor 2, Desember, Universitas Kebangsaan, Bandung.

[3] Christalia M. S. Bororing dkk., 2019, Penataan Sistem Saluran Drainase di Jalan Batukota, Winangun Satu Kecamatan Malalayang Kota Manado, Statik Vol.7 No. 6 Juni Universitas Sam Ratulangi Manado.

[4] Aditya W. Dethan dkk., 2020, Perencanaan Saluran Drainase pada Kecamatan Kota Soe, Jurnal Teknik Sipil, Vol. IX, No. 2, September, Universitas Petra, Surabaya.

[5] Anisah Lukman,2018, Evaluasi Sistem Drainase di Kecamatan Helvetia Kota Medan, Buletin Utama Teknik, Vol. 13, No. 2, Januari, Universitas Islam Sumatra Utara, Medan.

[6] Suripin, 2004, Sistem Drainase Perkotaan yang Berkelanjutan, Yogyakarta.

[7] Arie Setyawan dkk., 2018, Pengaruh Perubahan Tata Guna Lahan Terhadap Debit Saluran Drainase Jalan Arifin Ahmad pada Ruas antara Jalan Rambutan dengan Jalan Paus Ujung di Kota Pekanbaru, Jurnal Saintis Volume 18 Nomor 2, Oktober, Universitas Islam Riau.

[8] Fitra Andika Parse, 2018, Perencanaan Saluran Drainase dengan Analisis Debit Banjir Metode Rasional, Studi Kasus Desa Petapahan Kecamatan Gunung Toar, Jupersatek Vol. 1, No. 2, Desember, Universitas Islam Kuantan Singingi, Riau.

[9] Usaamah Hadi dkk. 2019, Evaluasi Kinerja Sistem Drainase pada wialayah Kelurahan Medokan Ayu Kota Surabaya, Jurnal Rekayasa Sipil dan Lingkungan, Vol. 3, No. 1, Universitas Jember, Jember.

[10] Muhamad Arifin, 2018, Evaluasi Kinerja Sistem Drainase Perkotaan di Wilayah Purwokerto, Jurnal Teknik Sipil Vol. XIII No.1, Februari 2018, Universitas Cokroaminoto, Yogyakarta.

[11] Titon Sadewa dkk., 2018, Kajian Sistem Drainase di Daerah Jalan Pemuda Kota Bogor Jurnal Teknik Sipil dan Lingkungan, Vol. 03 No. 03, Desember, Institut Pertanian Bogor, Bogor. 